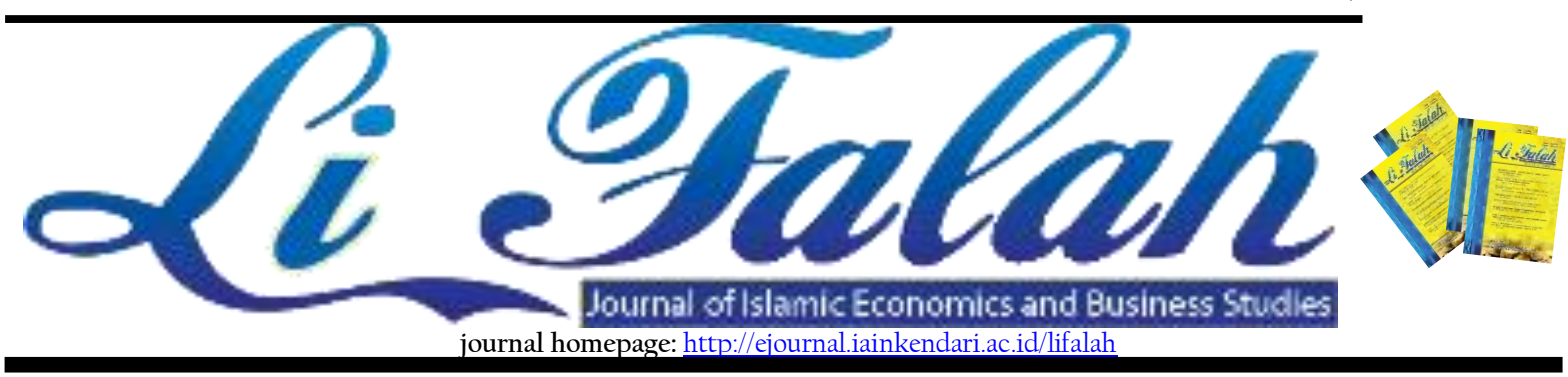

\title{
Analysis of Investment Decisions at BMT Latansa Gontor Ponorogo
}

\section{Apriliana Ika Kusumanisita ${ }^{1}$, Lathiefa Rusli ${ }^{2}$, Raditya Iqbal Anugrah ${ }^{3}$ \\ 1,2,3 Universitas Darussalam Gontor \\ e-cmail: *laprilianaikakusumanisita@unida.gontor.ac.id, 2 lathiefarusli@unida.gontor.ac.id, 3raditya@mhs.unida.gontor.ac.id}

\begin{tabular}{|c|c|}
\hline ARTICLE INFO & A B S T R A C T \\
\hline $\begin{array}{l}\text { Article History: } \\
\text { Received } 15 \text { November } 2021 \\
1^{\text {st }} \text { Received in revised form } 15 \\
\text { December } 2021 \\
\text { Available online } 30 \text { December } 2020\end{array}$ & $\begin{array}{l}\text { This study aims to examine customer decisions in } \\
\text { investing in BMT. The theory used to predict } \\
\text { customer decisions in investing is the theory of } \\
\text { reasoned action. The research method used is } \\
\text { quantitative research with data analysis } \\
\text { techniques Structural Equation Modeling (SEM). }\end{array}$ \\
\hline $\begin{array}{l}\text { Keywords: } \\
\text { Investment Decision, Baitul Maal Wat } \\
\text { Tamwil, Theory of Reasoned Action. }\end{array}$ & $\begin{array}{l}\text { The results showed that the sharia system, product } \\
\text { knowledge, religiosity, attitudes, risk perception, } \\
\text { image, and investment intentions affected } \\
\text { investment decisions. }\end{array}$ \\
\hline
\end{tabular}

\section{Introduction}

BMT (Baitul Maal Wat Tamwil) is one of the sharia microfinance institutions that have a role in collecting and distributing funds to the community by adhering to sharia principles. The source of BMT's capital comes from loan capital collected from its members. The product for raising funds at BMT can be in the form of savings or time deposits. The amount of savings in sharia microfinance institutions in April 2021 was 71.80 billion, a decrease from the previous year, which was 72.88 billion. This decrease indicates limited activities during the pandemic, affecting customers' savings interest. In addition, time deposits in Islamic microfinance institutions in April 2021 amounted to 235.93 billion, an increase from the previous year of 218.74 billion (OJK, 2021). The high interest of customers to invest in sharia microfinance institutions is one of the factors for further research related to investment decisions in BMT. 


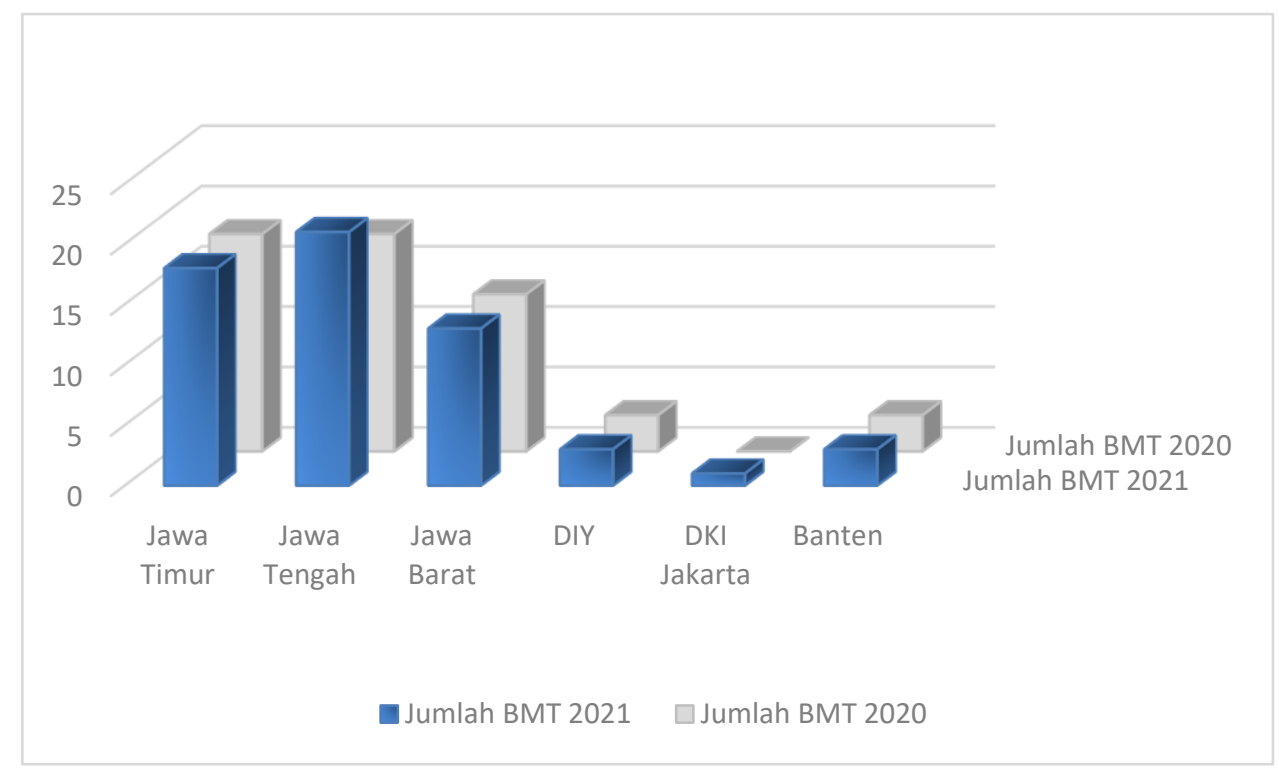

Source: OJK, 2021

The Financial Services Authority (OJK) recorded around 81 BMTs operating in Indonesia, with total assets reaching 499.70 billion. Based on the graph above, the number of BMTs operating in East Java reaches 18 BMTs, which is still low compared to Central Java, which is around 21 BMTs. East Java itself is often referred to as the city of santri, which has many Islamic boarding schools and has the largest market share to get a large enough number of customers. However, this is inversely proportional to the number of BMTs, which are relatively small compared to the Central Java region. This data indicates that further analysis is needed regarding investment decisions of BMT customers in the East Java region to attract public interest in saving.

BMT Latansa Gontor is a sharia microfinance institution located in the Ponorogo area, East Java, and is directly supervised by Pondok Modern Darussalam Gontor (PMDG). The BMT has a significant role in improving the community's welfare through its collection and financing products, especially for its members. Customers in making investment decisions have different views and mindsets on the concept of sharia microfinance institutions. The low level of financial literacy will affect the choice of customers to invest in BMT (Effendi, et., al., 2020). One of the theories that can explain customers' investment decisions in using BMT services is the theory of reasoned action proposed by Ajzen and Fishbein (1975).

The issues raised in this study are related to investment decisions in BMT Latansa Gontor Ponorogo. According to Effendi et al. (2020), the factors that influence investment decisions are the sharia system, product knowledge, promotions, services, attitudes, subjective norms, and the intention to use the services of Sharia BPR. His research shows that the shari'ah system, promotions, services, attitudes, subjective norms, and intentions significantly affect the use of Sharia BPR services. In contrast, product knowledge has no significant effect on 
attitudes. Heart et al. (2020) showed different results from previous researchers, namely, product knowledge did not directly affect customer intentions to invest in Islamic banks. However, when mediated by perceived quality and risk, it significantly affects customer intentions to invest in Islamic banks. Based on the above background, the problem in this research is what factors influence investment decisions in BMT Latansa Gontor Ponorogo?

\section{Literature Review}

An explanation of customer investment decisions in BMT can be explained through the theory of reasoned action proposed by Ajzen and Fishbein (1975). The theory consists of two factors related to personal and social influence. Personal factors refer to attitudes that can evaluate positive or negative factors in behavior, while social refers to a person's norms or perceptions of social pressure in acting. According to Ajzen (1991), the stronger a person's intention to perform a specific behavior, the greater the behavior. The theory is used to examine the relationship between attitudes, beliefs, behavior, and intentions (Janah et al., 2020). Nature et al. (2012) also developed a theory of reasoned action to determine a person's level of religiosity to use Islamic finance in the Klang Valley, Malaysia.

Research shows that many factors influence investment decisions in Islamic banks, including the sharia system, product knowledge, promotions, services, attitudes, subjective norms, intentions, perceived quality, perceived risk, perceived value, community influence, religiosity, image, and trust. (Effendi et. al., 2020; Hati et. al., 2020; Janah et. al., 2020; Hassan and Abbas, 2020). The religiosity factor is one of the essential factors for making investment decisions. Islamic principles prohibit usury (interest), maisir (gambling), and gharar (speculative) in the concept of transactions in Islamic banks (Effendi et al., 2020).

Effendi et al. (2020) examine the factors that influence investment decisions, namely the sharia system, product knowledge, promotions, services, attitudes, subjective norms, and the intention to use the services of Sharia BPR. His research shows that Sharia compliance, promotion, service, attitudes, subjective norms, and intentions significantly affect the use of Sharia BPR services. In contrast, product knowledge has no significant effect on attitudes.

Liver et al. (2020) showed different results from previous researchers. Namely, product knowledge did not directly affect customer intentions to invest in sharia bank deposits. However, when mediated by perceived quality and risk, it significantly affects customer intentions to invest in Islamic bank deposits. Suhartanto (2019) examines religiosity, trust, and image across customers and non-customers on Islamic banks' behavioral intentions. The results show that religiosity is an important determinant of trust, image, and loyalty from a sample of Islamic bank customers. 
Meanwhile, from a sample of non-customers, this study shows that religiosity is also an essential factor for trust, image, and behavioral intentions towards Islamic banks. Religiosity significantly affects behavioral intention compared to belief and image effect. The influence of religiosity on behavioral intention is the weakest. In addition, the mediation test shows that in addition to the direct effect, the influence of religiosity on behavioral intentions is through image and belief mediation. Thus, the proposed hypothesis is as follows:

Hl: The Shari'ah system affects attitudes

H2: Product knowledge affects risk

H3: Religiosity affects image

H4: Attitude affects intentions

H5: Perception of risk affects intention

H6: Image affects intentions

H7: Investment intentions affect investment decisions

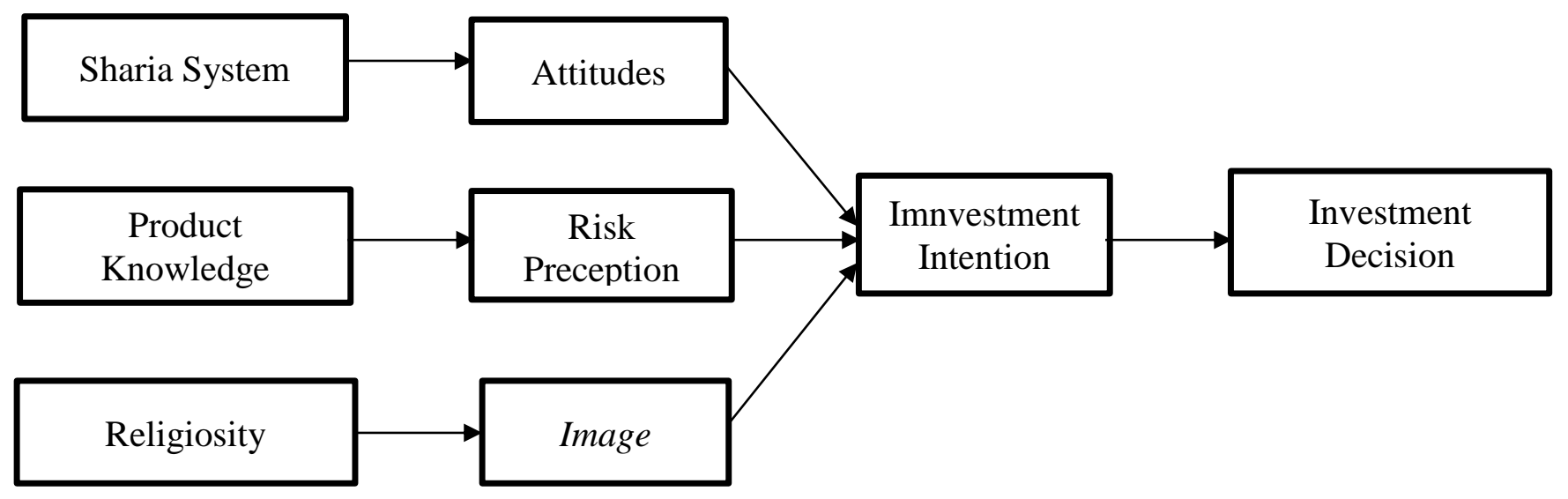

Figure 1. Factors Affecting Investment Decisions in BMT

\section{Research Method}

The research method used is quantitative research. Data were collected through questionnaires distributed to respondents who invested their funds in Barokah, Mabrur, and Mahir products. The variables to be tested are the sharia system, product knowledge, attitudes, risk perception, religiosity, image, intentions, and customer decisions in investing in BMT. The items comprising the underlying subscales were adjusted and modified according to the needs of the study taken from Effendi et al. (2020), Hati et al. (2020), and Suhartanto (2019). Respondents were selected using a non-probability sampling technique with a purposive sampling approach. The data analysis technique used is Structural Equation Modeling (SEM). 


\section{Result}

\subsection{PLS Analysis}

Hypothesis testing in this study was carried out using the Partial Least Square (PLS) analysis technique with the help of the Smart pls program. The PLS model specifications that will be estimated in this study are as follows:

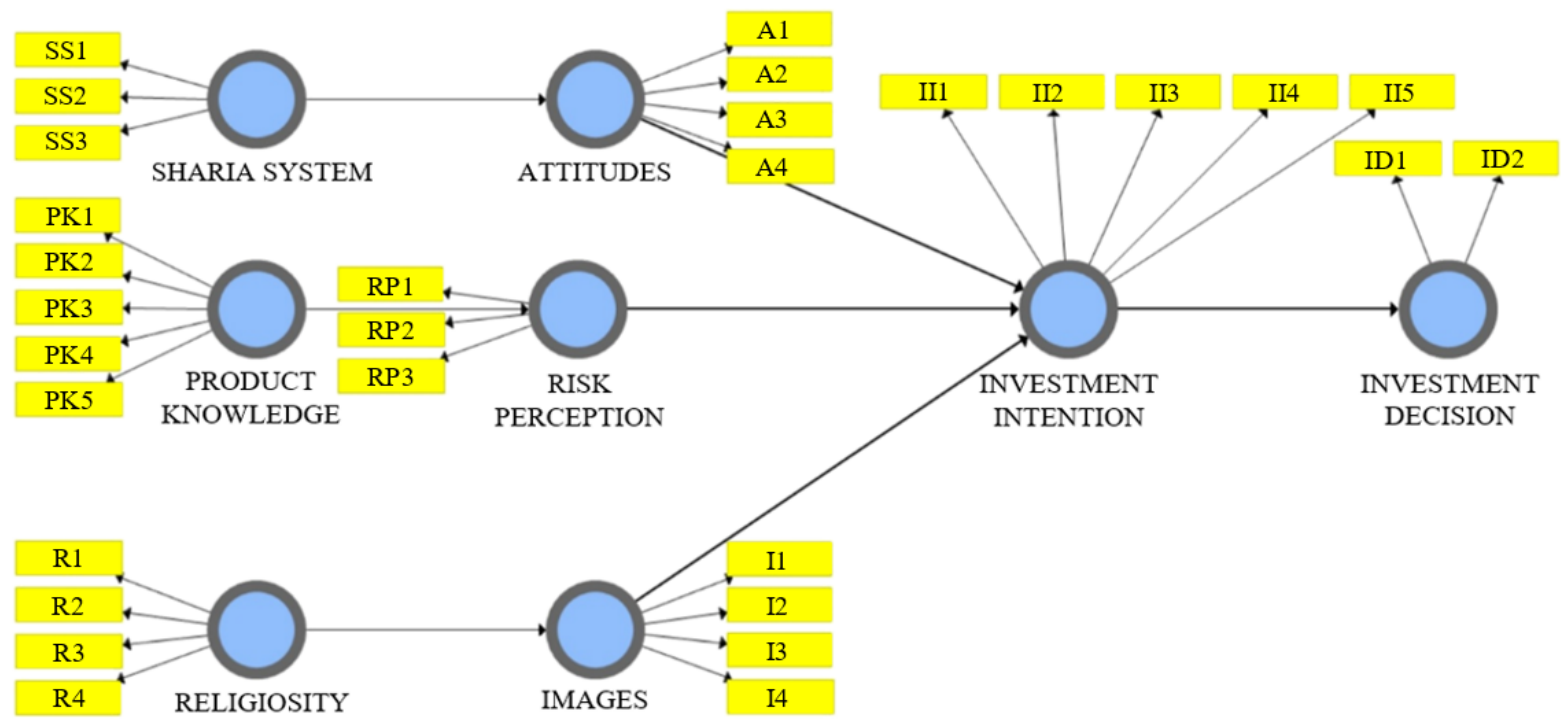

Figure 2. PLS Model Spesification

The stages in this PLS analysis include the outer model testing phase and the inner model testing phase. The outer model testing phase is used to test the validity and reliability of all indicators in measuring their constructs. In contrast, inner model testing is used to test research hypotheses.

Table 1 shows that all PLS model indicators have a loading factor value $>0.7$, and all constructs have an AVE > 0.5 so that it can be stated that the PLS model has met the required convergent validity criteria. The results of the composite reliability test in Table 1 show that all constructs have met the required composite reliability criteria as indicated by the Cronbachs alpha value $>0.7$ and composite reliability $>0.7$.

Table 2 shows the required discriminant validity criteria, such as the square root value of the AVE of all constructs having exceeded the correlation between the constructs and other constructs. HTMT value of the constructs, which did not exceed 0.9, means that each construct's discriminant validity has been met. 
Table l. Convergent Validity and Reliability

\begin{tabular}{|c|c|c|c|c|c|c|c|}
\hline Variable & Indikator & $\begin{array}{l}\text { Loading } \\
\text { Factor }\end{array}$ & AVE & $\begin{array}{l}\text { Validity } \\
\text { Konvergen }\end{array}$ & $\begin{array}{c}\text { Cronbach's } \\
\text { Alpha }\end{array}$ & $\begin{array}{l}\text { Composite } \\
\text { Reliability }\end{array}$ & Reliability \\
\hline \multirow[t]{4}{*}{ Image } & $\mathrm{Il}$ & 0.897 & \multirow[t]{4}{*}{0.836} & valid & \multirow[t]{4}{*}{0.935} & \multirow[t]{4}{*}{0.953} & reliabel \\
\hline & $\mathrm{I} 2$ & 0.913 & & valid & & & reliable \\
\hline & I3 & 0.905 & & valid & & & reliable \\
\hline & $\mathrm{I} 4$ & 0.941 & & valid & & & reliable \\
\hline \multirow{2}{*}{$\begin{array}{l}\text { Keputusan } \\
\text { Investasi }\end{array}$} & KIl & 0.959 & \multirow[t]{2}{*}{0.909} & valid & \multirow[t]{2}{*}{0.900} & \multirow[t]{2}{*}{0.952} & reliabel \\
\hline & KI2 & 0.948 & & valid & & & reliable \\
\hline \multirow{5}{*}{$\begin{array}{c}\text { Niat } \\
\text { Investasi }\end{array}$} & NIl & 0.959 & \multirow[t]{5}{*}{0.912} & valid & \multirow[t]{5}{*}{0.976} & \multirow[t]{5}{*}{0.981} & reliabel \\
\hline & NI2 & 0.932 & & valid & & & reliable \\
\hline & NI3 & 0.958 & & valid & & & reliable \\
\hline & NI4 & 0.961 & & valid & & & reliable \\
\hline & NI5 & 0.965 & & valid & & & reliable \\
\hline \multirow{5}{*}{$\begin{array}{l}\text { Pengetahuan } \\
\text { Produk }\end{array}$} & $\mathrm{PPl}$ & 0.910 & \multirow[t]{5}{*}{0.836} & valid & \multirow[t]{5}{*}{0.951} & \multirow[t]{5}{*}{0.962} & reliabel \\
\hline & PP2 & 0.907 & & valid & & & reliable \\
\hline & PP3 & 0.928 & & valid & & & reliable \\
\hline & PP4 & 0.942 & & valid & & & reliable \\
\hline & PP5 & 0.885 & & valid & & & reliable \\
\hline \multirow{3}{*}{$\begin{array}{l}\text { Persepsi } \\
\text { Resiko }\end{array}$} & PRl & 0.894 & \multirow[t]{3}{*}{0.839} & valid & \multirow[t]{3}{*}{0.905} & \multirow[t]{3}{*}{0.940} & reliabel \\
\hline & PR2 & 0.928 & & valid & & & reliable \\
\hline & PR3 & 0.927 & & valid & & & reliable \\
\hline \multirow[t]{4}{*}{ Religiusitas } & $\mathrm{Rl}$ & 0.933 & \multirow[t]{4}{*}{0.894} & valid & \multirow[t]{4}{*}{0.960} & \multirow[t]{4}{*}{0.971} & reliabel \\
\hline & R2 & 0.950 & & valid & & & reliable \\
\hline & R3 & 0.943 & & valid & & & reliable \\
\hline & $\mathrm{R} 4$ & 0.956 & & valid & & & reliable \\
\hline \multirow[t]{4}{*}{ Sikap } & Sl & 0.891 & \multirow[t]{4}{*}{0.881} & valid & \multirow[t]{4}{*}{0.955} & \multirow[t]{4}{*}{0.967} & reliabel \\
\hline & S2 & 0.974 & & valid & & & reliable \\
\hline & S3 & 0.931 & & valid & & & reliable \\
\hline & S4 & 0.957 & & valid & & & reliable \\
\hline \multirow{3}{*}{$\begin{array}{l}\text { Sistem } \\
\text { Syariah }\end{array}$} & SSl & 0.951 & \multirow[t]{3}{*}{0.885} & valid & 0.935 & 0.958 & reliabel \\
\hline & SS2 & 0.917 & & valid & & & reliable \\
\hline & SS3 & 0.953 & & valid & & & reliable \\
\hline
\end{tabular}

Table 2. Descriminant Validity

\begin{tabular}{ccccccccc}
\hline Variable & IM & KI & NI & PP & PR & REL & SI & SS \\
\hline IM & 0,914 & & & & & & & \\
\hline KI & 0,763 & 0,954 & & & & & & \\
\hline NI & 0,825 & 0,925 & 0,955 & & & & & \\
\hline PP & 0,766 & 0,845 & 0,848 & 0,914 & & & & \\
\hline PR & 0,663 & 0,779 & 0,797 & 0,916 & 0,916 & & & \\
\hline REL & 0,888 & 0,825 & 0,834 & 0,824 & 0,790 & 0,946 & & \\
\hline SI & 0,797 & 0,804 & 0,862 & 0,839 & 0,752 & 0,824 & 0,939 & \\
\hline SS & 0,710 & 0,685 & 0,728 & 0,779 & 0,624 & 0,690 & 0,865 & 0,940 \\
\hline
\end{tabular}


The inner model test includes an assessment of the Goodness of fit structural model, an assessment of the path coefficient, a test of the significance of the partial effect of exogenous variables on endogenous variables, and the calculation of the coefficient of determination. The test results at this stage can be used to test the research hypothesis.

The PLS model's Goodness of fit can be assessed from the R Square value, the Q Square value, and the SRMR value. The value of $R$ square is categorized into three categories, namely sound, moderate and weak. According to Chin (1998), the R square value of 0.67 indicates that the PLS model is robust, 0.33 indicates the PLS model is in the moderate category, and 0.19 indicates that the PLS model is in the weak category. The value of Q square is categorized into three categories: small, medium, and large, the value of $Q$ square of 0.02 is declared minor, the value of $\mathrm{Q}$ square of 0.15 is declared moderate, and the value of Q square of 0.35 is declared significant. The SRMR value is categorized into two categories: the perfect fit model if the SRMR < 0.08; the model is fit if the SRMR is between $0.08-0.10$, and the model is not fit if the SRMR is > 0.10. The Goodness of fit model test results in Table 3 shows the model has good criteria because it has an endogenous $\mathrm{R}$ Square in the solid and moderate categories and has a large Q Square and an SRMR between 0.08 - 0.10 that the model is stated in the fit category.

Table 3. Goodness of fit Model PLS

\begin{tabular}{cccc}
\hline \multirow{2}{*}{$\begin{array}{c}\text { Endogen } \\
\text { Variable }\end{array}$} & \multicolumn{3}{c}{ The Goodness of fit Model Parameter } \\
\cline { 2 - 4 } & R Square & Q Square & SRMR \\
\hline IM & 0,789 & 0,631 & 0.066 \\
\hline KI & 0,855 & 0,772 & \\
\hline NI & 0,832 & & \\
\hline PR & 0,839 & 0,693 \\
\hline SI & 0,747 & 0,639 & \\
\hline R Square: 0.67 strong; 0.33 moderate; 0.19 weak. Q Square: 0.02 small; 0.15 medium; 0,35 big. SRMR : $<0.10$ fit
\end{tabular}

The evaluation results of the path coefficients in Table 4 show that the path coefficients of attitudes towards investment intentions are the largest compared to the path coefficients on the relationship between risk perception and image on investment intentions. This data shows that attitude is the most influential factor on customer intention to invest. 


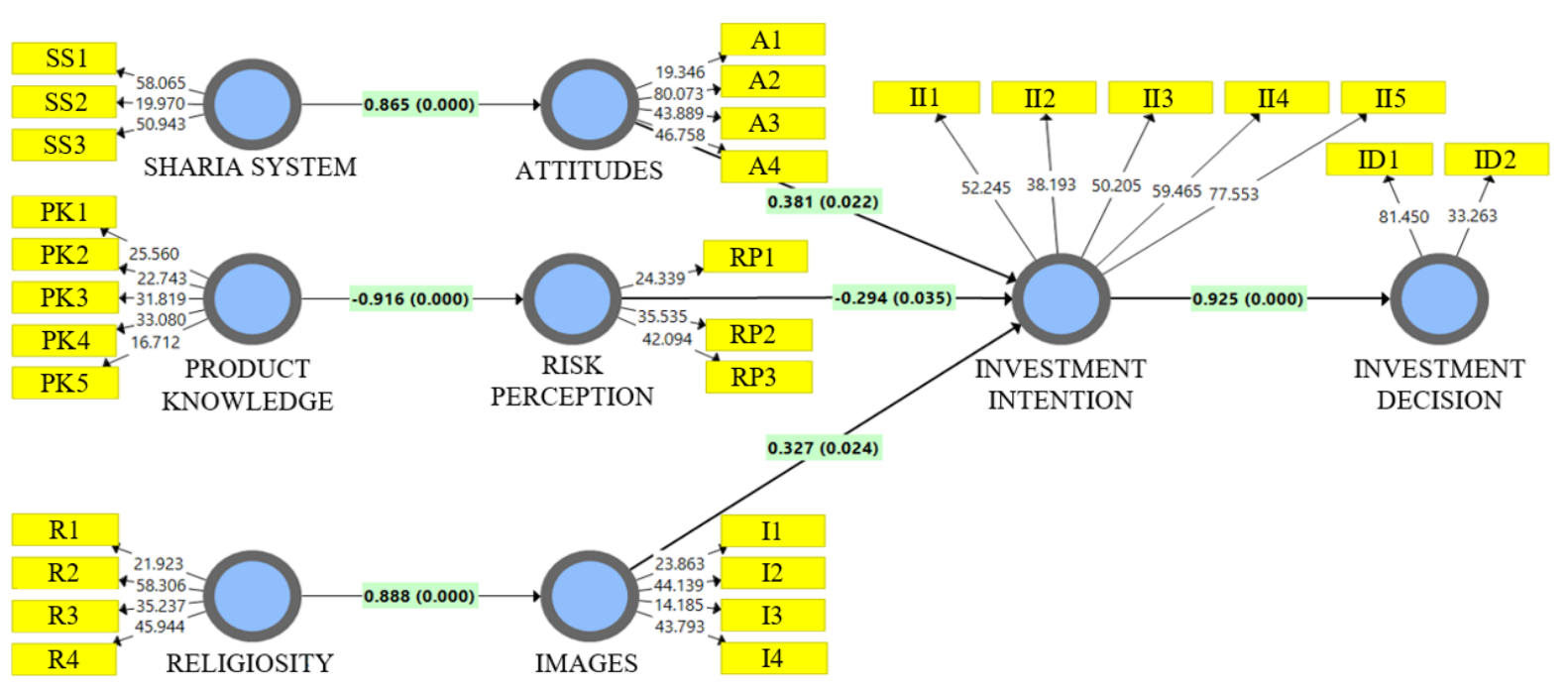

Figure 3.

PLS Model Estimation Results - Bootstrapping

Table 4. Dirrect Effect

\begin{tabular}{clccc}
\hline & Dirrect Path & Path Coefficient & T Statistics & P Values \\
\hline$\bullet$ & IM $\rightarrow$ NI & 0.327 & 2.263 & 0.024 \\
\hline$\bullet$ & NI $\rightarrow$ KI & 0.925 & 37.078 & 0.000 \\
\hline$\bullet$ & PP $\rightarrow$ PR & -0.916 & 24.991 & 0.000 \\
\hline$\bullet$ & PR $\rightarrow$ NI & -0.294 & 2.109 & 0.035 \\
\hline$\bullet$ & REL $\rightarrow$ IM & 0.888 & 18.358 & 0.000 \\
\hline$\bullet$ & SI $\rightarrow$ NI & 0.381 & 2.296 & 0.022 \\
\hline$\bullet$ & SS $\rightarrow$ SI & 0.865 & 14.225 & 0.000 \\
\hline
\end{tabular}

Significant level 5\%; koefisien jalur signifikan jika p value <0,05 dan T statistik > 1,96

Table 5. Indirrect Effect

\begin{tabular}{|c|c|c|c|}
\hline Indirrect Path & Path Coefficient & T Statistics & P Values \\
\hline - $\mathrm{IM} \rightarrow \mathrm{NI} \rightarrow \mathrm{KI}$ & 0.302 & 2.241 & 0.025 \\
\hline - $\mathrm{SS} \rightarrow \mathrm{SI} \rightarrow \mathrm{NI}$ & 0.329 & 2.240 & 0.026 \\
\hline - $\quad \mathrm{PR} \rightarrow \mathrm{NI} \rightarrow \mathrm{KI}$ & -0.272 & 2.113 & 0.035 \\
\hline - $\mathrm{REL} \rightarrow \mathrm{IM} \rightarrow \mathrm{NI} \rightarrow \mathrm{KI}$ & 0.269 & 2.162 & 0.031 \\
\hline - $\quad \mathrm{SS} \rightarrow \mathrm{SI} \rightarrow \mathrm{NI} \rightarrow \mathrm{KI}$ & 0.304 & 2.233 & 0.026 \\
\hline - $\mathrm{SI} \rightarrow \mathrm{NI} \rightarrow \mathrm{KI}$ & 0.352 & 2.302 & 0.022 \\
\hline - $\quad \mathrm{PP} \rightarrow \mathrm{PR} \rightarrow \mathrm{NI}$ & 0.269 & 2.075 & 0.039 \\
\hline - $\mathrm{REL} \rightarrow \mathrm{IM} \rightarrow \mathrm{NI}$ & 0.291 & 2.190 & 0.029 \\
\hline - $\quad \mathrm{PP} \rightarrow \mathrm{PR} \rightarrow \mathrm{NI} \rightarrow \mathrm{KI}$ & 0.249 & 2.074 & 0.039 \\
\hline
\end{tabular}

Significant level 5\%; koefisien jalur signifikan jika p value $<0,05$ dan T statistik $>1,96$

Based on the test results, the following results were obtained: In the path that shows the influence of the sharia system on attitudes (SS S), the p-value obtained is 0.000 with a T statistic of 14.225 and a positive path coefficient of 0.865 . Because the path $\mathrm{p}$-value $<0.05, \mathrm{~T}$ 
statistic >1.96, and the path coefficient is positive, it can be concluded that the sharia system has a positive effect on customer attitudes. This finding means that the better the sharia system, the better customer attitudes. This data supports hypothesis 1 in this study so that hypothesis 1 is proven (accepted).

In the path that shows the effect of product knowledge on risk perception (PP PR), the p-value obtained is 0.000 with a T statistic of 24.991 and a negative path coefficient of -0.916 . Because the path $\mathrm{p}$-value $<0.05$, T statistic $>1.96$, and the path coefficient is negative, it can be concluded that product knowledge has a negative and significant effect on customer risk perceptions. The higher the customer's knowledge of the product to be invested in, the lower the customer's risk perception. This finding supports hypothesis 2 in this study so that hypothesis 2 is proven (accepted).

In the path that shows the effect of religiosity on the image (REL IM), the p-value obtained is 0.000 with a $\mathrm{T}$ statistic of 18.358 , and the path coefficient is positive at 0.888 . Because the path $\mathrm{p}$-value $<0.05$, T statistic $>1.96$, and the path coefficient is positive, it can be concluded that religiosity has a positive and significant effect on the image. The higher the religiosity, the better the image. This data supports hypothesis 3 in this study so that hypothesis 3 is proven (accepted). In the path that shows the effect of attitude on investment intention (S NI), the p-value obtained is 0.022 with a T statistic of 2.296 and a positive path coefficient of 0.381. Because the path $\mathrm{p}$-value $<0.05$, T statistic $>1.96$, and the path coefficient is positive, it can be concluded that attitude has a positive effect on investment intention. This finding means that the higher the altitude, the higher the investment intention. This data supports hypothesis 4 in this study so that hypothesis 4 is proven (accepted)

In the path that shows the effect of risk perception on investment intention (PR NI), the $\mathrm{p}$-value obtained is 0.035 with a T statistic of 2.109 and a negative path coefficient of -0.294 . Because the path $\mathrm{p}$-value $<0.05$, T statistic $>1.96$, and the path coefficient is negative, it can be concluded that risk perception has a negative effect on investment intention. This finding means that the lower the risk perception, the higher the investment intention. This finding supports hypothesis 5 in this study so that hypothesis 5 is proven (accepted). In the path that shows the effect of image on investment intention (IM NI), the p-value obtained is 0.024 with a T statistic of 2.263 and a positive path coefficient of 0.327 . Because the path $\mathrm{p}$-value $<0.05, \mathrm{~T}$ statistic $>1.96$, and the path coefficient is positive, it can be concluded that image has a positive effect on investment intention. This finding means that the higher the image, the higher the investment intention. This finding supports hypothesis 6 in this study so that hypothesis 6 is proven (accepted). In the path that shows the effect of investment intention on investment decisions (NID KI), the p-value obtained is 0.022 with a $\mathrm{T}$ statistic of 37.078 , and the path 
coefficient is positive at 0.925 . Because the path $\mathrm{p}$-value $<0.05$, T statistic $>1.96$, and the path coefficient is positive, it can be concluded that investment intention has a positive effect on investment decisions. This data means that the higher the investment intention, the higher the investment decision. This finding supports hypothesis 7 in this study so that hypothesis 7 is proven (accepted).

\section{Discussion}

This study examines investment decisions at BMT Latansa Gontor Ponorogo. This study indicates that the sharia system affects customer attitudes to BMT investment. Several previous studies have stated that sharia compliance is the most critical factor in influencing customer attitudes toward Islamic banking services (Kaakeh et al., 2019). Sharia compliance in Islamic banks is the highest factor in determining customer perceptions of Islamic banking (Big et al., 2009; Muhamad, 2015). In addition, Dusuki and Abdullah (2007) state that bank compliance with sharia principles is an essential factor for Islamic bank customers.

Meanwhile, the effect of product knowledge on risk perception is significant. Companies that provide essential information about their products and services can help customers develop product knowledge to reduce consumer uncertainty about certain products (Eisingerich and Bell, 2008). It is different if there is no product knowledge about the characteristics of term deposits in Islamic banks. Customers will perceive that the risk of investing in Islamic banks is higher than the risk of investing in conventional banks (Hati et al., 2020).

The image of a bank is a consequence of the relationship between beliefs, experiences, feelings, impressions, and knowledge that a person has about banking (Muslim et al., 2013). The results of this study indicate that religiosity has a significant effect on the image. These results follow Suhartanto's (2019) research, which shows that religiosity determines the image. When customers are more committed to their religion, they tend to have a positive image of Islamic banking. This finding also strengthens previous research on the positive relationship between religiosity and image (Muslim et al., 2013).

Jannah (2020), Effendi (2020), and Ganesan (2020) state that there is a significant relationship between customer attitudes and intentions to use Islamic banking services. Abbass and Tanveer (2019) and Ali et al. (2019) also states that attitude plays a vital role in determining choices in the use of Islamic banking services, so that the stronger a person's attitude is, the greater their intention to use these services (Jaffar and Musa, 2016). This study follows previous studies that showed that attitudes affect a person's intention to invest in BMT Latansa Gontor. The results of this study indicate that the perception of risk has a 
significant effect on one's investment intentions. Intention to invest is a type of financial behavior. Customers are expected to get positive consequences from the products offered by Islamic banking. However, when customers face the potential negative consequences of using a product (perceived risk), it can reduce their intention to invest in the Islamic banking product (Stone and Gronhaug, 1993). Research by Croy et al. (2010) and Hati (2020) show that risk perception significantly affects investment intentions.

In addition, the results of this study indicate that image has a significant effect on one's investment intentions in BMT Latansa Gontor. Research by Hoq et al., 2010; Muslim et al., 2013; Saleh et al., 2017 showed a positive influence between the image on customer behavioral intentions towards Islamic banking. The results of this study are also supported by Suhartanto's research (2019) which shows that image has a significant effect on one's investment intentions. Perilaku seseorang merupakan fungsi dari niat yang kompatibel (Ajzen, 1991). The intention is a critical behavior that helps managers align their strategies and decisions in the market (Tsiotsou, 2006). Bianchi et al. (2019) state that intention is crucial for any behavior. The results of this study indicate that investment intention has a significant effect on a person's decision. This study is in line with research conducted by Effendi (2020), which states that investment intention has a significant effect on a person's decision to use Islamic banking services.

\section{Conclusion}

This study indicates that the sharia system, product knowledge, religiosity, attitude, risk perception, image, and investment intention significantly affect investment decisions at BMT Latansa Gontor. Product knowledge provides essential information on customer perceptions of product and service quality to mitigate existing risks. Good product knowledge will be in line with image enhancement which can increase the level of trust from customers. However, BMT Latansa Gontor needs to improve the view of customers' different mindsets and perceptions to keep their intentions straight towards their investment decisions. 


\section{References}

Abbass, K. \& Tanveer, A. (2019). Factors affecting the adoption of Islamic banking of Pakistan. Journal of Islamic Banking and Finance, 36 (3), 83-101.

Ajzen, I. (1991). The theory of planned behavior. Organizational behavior and human decision processes, 50 (2), 179-211.

Ali, Q., Yaacob, H.B. \& Mahalle, N. (2019). An empirical investigation of Islamic banking adoption in Brunei. COMSATS Journal of Islamic Finance, 4 (1), 24-45.

Besar, M., Sukor, M.E.A., Muthalib, N.A. \& Gunawa, A.Y. (2009). The practice of shariah review as undertaken by Islamic banking sector in Malaysia. International Review of Business Research Papers, 5, 294-306.

Bianchi, E., Bruno, J.M. \& Sarabia-Sanchez, F.J. (2019). The impact of perceived CSR on corporate reputation and purchase intention. European Journal of Management and Business Economics.

Chin, W. W. (1998). The partial least squares approach to structural equation modeling. Modern methods for business research, 295 (2), 295-336.

Croy, G., Gerrans, P. \& Speelman, C. (2010). The role and relevance of domain knowledge, perceptions of planning importance, and risk tolerance in predicting savings intentions. Journal of Economic Psychology, 31 (6), 860-871.

Dusuki, A.W. \& Abdullah, N.I. (2007). Why do Malaysian customers patronize Islamic banks?. International Journal of Bank Marketing, 25 (3), 142-160.

Effendi, I., Murad, M., Rafiki, A., \& Lubis, M. M. (2020). Applying the theory of reasoned action on services of Islamic rural banks in Indonesia. Journal of Islamic Marketing.

Eisingerich, A.B. \& Bell, S.J. (2008). Perceived service quality and customer trust: does enhance customers' service knowledge matter?. Journal of Service Research, 10 (3), 256-268.

Ganesan, Y., Pitchay, A. B. A., \& Nasser, M. A. M. (2020). Does intention influence the financial literacy of depositors of Islamic banking? A case of Malaysia. International Journal of Social Economics, 47 (5), 675-690.

Hassan, H. A., \& Abbas, S. K. (2019). Factors influencing the investors' intention to adopt Takaful (Islamic insurance) products: a survey of Pakistan. Journal of Islamic Marketing.

Hati, S. R. H., Wibowo, S. S., \& Safira, A. (2020). The antecedents of Muslim customers' intention to invest in an Islamic bank's term deposits: evidence from a Muslim majority country. Journal of Islamic Marketing.

Hoq, M.Z., Sultana, N. \& Amin, M. (2010). The effect of trust, customer satisfaction, and image affect customers' loyalty in the Islamic banking sector. South Asian Journal of Management, 17 (1), 70-93.

Jaffar, M.A. \& Musa, R. (2016). Determinants of attitude and intention towards Islamic financing adoption among Non-Users. Procedia Economics and Finance, 37 (16), 227-233.

Janah, N., Medias, F., \& Pratiwi, E. K. (2020). The intention of religious leaders to use Islamic banking services: the case of Indonesia. Journal of Islamic Marketing.

Kaakeh, A., Hassan, M.K. \& Almazor, S.F.V.H. (2019). Factors affecting customers' attitude towards Islamic banking in UAE. International Journal of Emerging Markets, 14 (4), 668-688.

Muhamad, R. (2015). Shariah compliance process and corporate governance in Islamic banking institutions (IBIs): a proposed model. Journal of Accounting Perspectives, 4, 36-48.

Muslim, A., Zaidi, I. and Rodrigue, F. (2013). Islamic banks: contrasting the drivers of customer satisfaction on image, trust, and loyalty of Muslim and non-muslim customers in Malaysia. International Journal of Bank Marketing, 31 (2), 79-97.

OJK. (2020). Statistik IKNB Syari'ah Periode April 2021. https://www.ojk.go.id/id/kanal/syariah/data-dan-statistik/iknb-syariah/Pages/StatistikIKNB-Syariah-Periode-April-2021.aspx

Saleh, M.A., Quazi, A., Keating, B. \& Gaur, S. (2017). Quality and image of banking services: a 
comparative study of conventional and Islamic banks. International Journal of Bank Marketing, 35 (6), 878-902.

Stone, R.N. \& Grønhaug, K. (1993). Perceived risk: further considerations for the marketing discipline. European Journal of Marketing, 27 (3), 39-50.

Suhartanto, D. (2019). Predicting behavioral intention toward Islamic bank: a multi-group analysis approach. Journal of Islamic Marketing.

Tsiotsou, R. (2006). The role of perceived product quality and overall satisfaction on purchase intentions. International Journal of Consumer Studies, 30 (2), 207-217. 